\title{
PENDAMPINGAN PEMBELAJARAN BAHASA INGGRIS BAGI SISWA SD DAN SMP DI RUMAH BELAJAR GNL DI DESA KERTAUNGARAN
}

\author{
Muhammad Aprianto Budie Nugroho \\ Muh.apriantobn@uniku.ac.id \\ Sheila Agustine \\ 2018410017@uniku.ac.id
}

\section{UNIVERSITAS KUNINGAN}

\begin{abstract}
ABSTRAK
Program pengabdian berupa pendampingan bagi siswa Sekolah Dasar dan Sekolah Menengah Pertama dalam belajar Bahasa Inggris dilakukan bertujuan untuk membantu para siswa dalam belajar Bahasa Inggris dari rumah selama pandemic Covid-19. Pendampingan ini dilakukan dengan latarbelakang kesulitan-kesulitan para siswa dalam belajar Bahasa Inggris dan kesulitan orang tua dalam membimbing belajar Bahasa Inggris. Olah karena itu, program pengabdian ini disambut baik diantara orang tua yang tinggal di Perum Griya Nyansa Lestari. Terdapat 6 siswa yang tergabung dalam program pengabdian ini, jumlah siswa dalam program ini dibatasi dikarenakan protocol covid-19. Para siswa terlihat antusias dalam belajar Bahasa Inggris dalam program ini. Hal tersebut bisa dilihat dari kehadiran mereka selama pembelajaran. Program ini akan berlanjut selama para siswa dalam masa belajar di rumah.
\end{abstract}

Kata kunci: Pendampingan Belajar, Bahasa Inggris, Task Based learning.

\section{PENDAHULUAN}

Virus Covid 19 yang bermula dari Wuhan China telah berdampak sangat signifikan pada dunia. Berdasarkan data WHO jumlah yang terinfeksi virus terebut sudah mencapai 34,3 juta penderita, dan virus covid 19 telah menelan korban jiwa sebanyak 1,02 juta jiwa di seluruh dunia saat ini. Sedangkan di Indonesia diperkirakan bahwa jumlah penderita yang terinfeksi virus tersebut kurang lebih 295 ribu orang dan meninggal lebih dari 10 ribu orang. Hal tersebut telah mempengaruhi roda ekonomi negara Indonesia dan menghentikan berbagai aktivitas di negara, baik aktivitas ekonomi maupun aktivitas pendidikan.
Semenjak diumumkan penderita pertama covid 19 di bulan Maret, pemerintah telah menghetikan semua aktivitas, terutama aktivitas yang berkaitan dengan pendidikan. Semua aktivitas yang berkaitan dengan pendidikan baik pengajaran dan pembelajaran dialihkan menjadi daring. Hal tersebut diputuskan oleh pemerintah dengan tujuan untuk menghentikan penyebaran Covid 19 pada guru dan murid-murid sekolah. Peralihan pengajaran dan pembelajaan dari tatap muka ke daring menimbulkan kesulitan-kesulitan baik bagi guru maupun para siswa. Para guru mengalami kesulitan dalam menyampaikan materi-materi pembelajaran secara efektif, dan siswa merasa kesulitan dengan 
pembelajaran jarak jauh karena tidak bisa secara langsung bertanya kepada guru apabila mengalami kesulitan.

Pembelajaran juga menyulitkan bagi orang tua, terutama orang tua yang tidak berlatar pendidikan tinggi, bahkan yang berlatar belakang pendidikan tinggi pun masih mengalami kesulitan pada mata pelajaran yang dianggap sulit, salah satunya bahasa Inggris. Dalam pengabdian ini, kami akan melaksanakan pengabdian dengan melakukan pendampingan pembelajaran bahasa Inggris bagi siswa SD dan SMP "Rumah Belajar" di lingkungan Perumahan Griya Nuansa Lestari yang terletak di Desa Kertaungaran, Kecamatan Sindangagung, Kabupaten Kuningan.

"Rumah Belajar" ini adalah sebuah gerakan keprihatinan yang digagas salah satu ibu rumah tangga yang bernama Dewi Puspasari, di sekitar perumahan tersebut yang merasa prihatin dengan kesulitan yang dihadapi oleh orang tua dalam pembelajaran daring sehari-hari. Oleh karena itu, muncul ide untuk mengadakan sebuah grup pembelajaran bagi siswa-siswa SD dan SMP di sekitar perumahan, bekerjasama dengan kelompok belajar yang dipimpin oleh ibu Dewi Puspasari S.E. Grup pembelajaran tersebut diharapkan dapat membantu para orang tua dan siswa dalam pembelajaran bahasa Inggris selama masa pandemic Covid 19 dengan tetap menjalan standar keamanan covid 19.

Dalam pendampingan belajar bahasa Inggris untuk anak-anak, Brown (2001) dalam bukunya mengemukakan bahwa dalam pembelajaran bahasa, seorang pengajar harus memperhatikan beberapa aspek yang salah satunya adalah sensory input. Pada umur pemula, anak-anak diharapkan menggunakan semua kelima inderanya dalam pembelajaran dan aktivitas pengajaran sebaiknya di luar visual dengan auditory model, yang biasanya bagi para pengajar merasa cukup pembelajaran di adakan di dalam kelas. Selain itu pengajaran bagi anak-anak/pemula harus memperhatikan perkembangan dari afektif anak-anak/pemula.
Pengabdian ini akan dilakukan dengan berbagai metode atau teknik pembelajaran yang sesuai dengan permasalahan yang dihadapi oleh anak-anak SD maupun SMP adalah. Salah satu pembelajaran yang bisa diterapkan adalah task-based learning. Ellis (2003) mengemukakan bahwa task-based learning adalah sebuah pembelajaran yang lebih menekankan pada makna dibandingkan struktur. Dalam penerapannya, siswa akan mendapatkan lebih banyak kesempatan untuk menggunakan bahasa Inggrisnya dalam berkomunikasi secara aktif seperti dalam kehidupan nyata. Siswa tidak lagi merasa takut dan cemas untuk melakukan kesalahan selama berkomunikasi dalam Bahasa Inggris. Menurut Sinantra (2009), hal tersebut sangat membantu para siswa untuk meningkatkan kemampuan berbicara mereka. Task-based learning mengacu pada suatu pembelajaran yang didasarkan pada penggunaan tugas sebagai unit inti dari perencanaan dan pengajaran dalam pengajaran bahasa (Skehan, 2003).

Selain itu terdapat beberapa penelitian yang menyarankan bahwa penggunaan Task Based learning sebagai salah satu pendekatan pembelajaran yang efektif. Beberapa penelitian tersebut adalah Rahmah (2016), Nurbani (2017), Apriliana (2018), dan Farhatunnisa (2019). Penelitianpenelitian mereka memperlihatkan bahwa pendekatan pembelajaran bahasa Inggris dengan menggunakan Task Based Learning kepada para siswa SD dan SMP memperlihatkan keberhasilan dalam pembelajaran Bahasa Inggris. Oleh karena itu, dalam pengabdian masyarakat dengan pendampingan pembelajaran bahasa Inggris bagi siswa SD dan SMP menggunakan pendekatan Task Based Learning.

\section{METODOLOGI PELAKSANAAN}

Berikut ini adalah langkah-langkah yang dilaksanakan dalam melakukan pengabdian berupa program pendampingan pembelajaran Bahasa Inggris bagi siswa SD dan SMP di Perumahan Griya Nuansa 
Lestari, Desa Kertaungaran, Kecamatan Sindangagung, Kabupaten Kuningan;

\section{Tahap Persiapan}

Persiapan dilaksanakan dengan mendata siswa yang akan mengikuti program pengabdian masyarakat. Pendataan ini dibantu oleh Ibu Dewi Puspasari dengan beberapa ibu rumah tangga di sekitar perumahan Griya Nuansa Lestari. Pembatasan jumlah siswa dilakukan dengan hanya fokus pada siswa-siswi SD dan kelas 7 dan siswa SMP di sekitar Blok M, N dan O. Hal tersebut dilakukan demi mematuhi protocol kesehatan dan keterbatasan ruang di Rumah Belajar GNL. Persiapan selanjutnya adalah pengadaan buku pembelajaran berupa LKS, whiteboard, dll.

2. Tahap Sosialisasi

Tahap sosialisasi ini dilanjutkan dengan pemberitahuan kepada para orang tua yang tinggal di Perumahan Griya Nuansa Lestari yang berada di sekitar Blok $\mathrm{M}, \mathrm{N}$ dan $\mathrm{O}$, dibantu Ketua Pelaksana Rumah Belajar yaitu ibu Dewi Puspasari yang nantinya ikut terlibat dalam pelaksanaan program pendampingan pembelajaran Bahasa Inggris, karena beliau pernah mengikuti program pendidikan Akta 4 pendidikan. Dari hasil sosialisasi terkumpul 8 orang siswa yang tersebar mulai dari 2 orang anak siswa kelas 1 SD, 2 orang siswa anak kelas 4 SD, 2 orang anak siswa kelas 5 SD dan 1 orang siswa kelas 7 SMP yang mengikuti program pengabdian masyarakat ini.

\section{Pelaksanaan Program}

Program pendampingan pembelajaran dilaksanakan mulai tanggal 6 Oktober 2020 hingga 6 November 2020 dengan pembelajaran tatap muka yang dilaksanakan secara luring atau luar jaringan di Rumah Belajar GNL yang berada di salah satu rumah di Blok O perumahan Griya Nuansa Lestari.

Kegiatan pengabdian berupa pendampingan pembelajaran Bahasa Inggris ditujukan bagi siswa-siswi SD dan SMP yang mengalami kesulitan selama masa pandemic berlangsung. Pembatasanpembatasan kegiatan belajar yang dilaksanakan di sekolah telah berlangsung kurang lebih satu tahun dan hal tersebut mendatangkan beberapa kesulitan baik bagi guru, siswa dan orang tua. Kesulitankesulitan tesebut timbul dikarenakan sarana prasarana internet. Hal tersebut membatasi interaksi antara guru dan siswa-siswinya, sedangkan tidak banyak orang tua yang mampu mendampingi dalam belajar berbagai mata pelajaran, salah satunya adalah Bahasa Inggris.

Oleh karena itu, kegiatan pengabdian masyarakat yang dilaksanakan adalah pendampingan pembelajaran Bahasa Inggris bagi siswa-siswi SD dan SMP. Kegiatan ini dilaksanakan di Rumah Belajar GNL di Perumahan Griya Nuansa Lestari yang terletak di Desa Kertaungaran, Kecamatan Sindangagung, Kabupaten Kuningan. Rumah Belajar GNL adalah sebuah tempat belajar bersama yang digagas oleh salah satu Ibu rumah tangga yang bernama ibu Dewi Puspasari beserta 2 ibu rumah tangga lainnya yang melihat berbagai kesulitan yang dihadapi oleh mereka dalam mendampingi pembelajaran putra-putri mereka. Kesulitan tersebut muncul karena tidak ada diantara para pengurus Rumah Belajar GNL menguasai Bahasa Inggris, sehingga mereka mengalami kesulitan dalam membimbing putra-putri mereka dalam mata pelajaran Bahasa Inggris.

Langkah pertama bagi tim kami yang lakukan dalam pendampingan pembelajaran Bahasa Inggris adalah melakukan observasi mengenai jumlah anak-anak sekolah di sekitar komplek yang membutuhkan pendampingan. Berdasarkan observasi terdapat 7 anak dalam rentang kelas 1 SD sampai dengan kelas 1 SMP. Setelah menentukan peserta dari pendampingan, selanjutnya tim mempersiapkan materi pembelajaran Bahasa Inggris yang sesuai dengan umur dan kelas anak-anak yang terlibat dalam pendampingan pembelajaran Bahasa Inggris salah satunya adalah dengan menggunakan Modul Pengayaan untuk kelas 5 dan kelas 1 SMP. Pemilihan Modul Pengayaan ditentukan berdasarkan kriteria dalam pengajaran bahasa untuk anak. Modul Pengayaan yang dipilih adalah Modul 
Pengayaan terbitan CV. Bina Pustaka. Berikut ini adalah modul yang digunakan dalam pendampingan pembelajaran bahasa Inggris untuk siswa SD dan SMP. Materi yang terdapat dalam modul pengayaan Bahasa Inggris terbitan CV. Bina Pustaka dianggap sesuai dengan umur dan tingkat pembelajaran Bahasa Inggris bagi anakanak yang terlibat dalam program pengabdian masyarakat. Selain itu, modul ini berkaitan dengan pendekatan yang akan digunakan dalam pengabdian ini yaitu Task Based Learning.

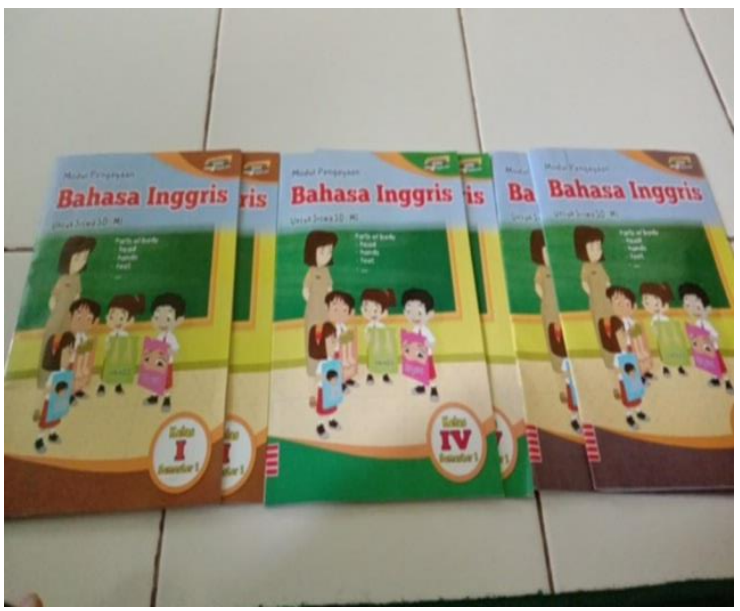

Gambar 1. Modul Pembelajaran

Setelah menentukan modul pengayaan yang akan digunakan, dilanjutkan dengan persiapan tempat yang akan digunakan. Kami memilih Rumah Belajar yang terletak di salah satu blok yaitu di Blok O, No. 06. Antusiasme para orang tua dalam program pengabdian masyarakat yang berupa pendampingan sangatlah besar tetapi berdasarkan Surat Edaran Nomer 15 Tahun 2020 tentang Pedoman Penyelenggaraan Belajar Dari Rumah Dalam Masa Darurat Penyebaran Corona Virus Disease (Covid 19), serta dengan keterbatasan ruang, maka peserta yang bisa mengikuti dibatasi jumlahnya. Berdasarkan diskusi dengan para pengurus Rumah Belajar GNL diputuskan hanya 5 orang untuk setiap sesi, demi menjaga kesehatan para peserta pendampingan pembelajaran.

Setelah itu, 7 (tujuh) orang anak yang masuk dalam pendampingan pembelajaran terdiri dari 2 orang anak kelas I SD, 2 orang anak kelas IV SD, 2 orang anak kelas V SD dan 1 orang anak kelas VII MTs. Ketujuh orang anak tersebut dikumpulkan di rumah belajar dan diadakan persiapan-persiapan sebelum dilaksanakan program yaitu sosialisasi program pendampingan pembelajaran Bahasa Inggris dan menentukan waktu pelaksanaan program tersebut. Berdasarkan kesepakatan dengan para peserta pendampingan pembelajaran Bahasa Inggris, maka diputuskan pelaksanaan akan dilaksanakan 3 kali seminggu, yaitu pada hari Selasa, Kamis dan Sabtu jam 09.30-10.45 WIB di Rumah Belajar GNL yang terletak di salah satu rumah di Perumahan Griya Nuansa Lestari. Berikut ini adalah photo pelaksanaan sosialisasi kegiatan Pendampingan Pembelajaran bahasa Inggris.

Selanjutnya adalah pelaksanaan pengabdian masyarakat berupa pendampingan pembelajaran yang dilaksanakan pada hari Selasa, Kamis dan Sabtu di mulai jam 09.30-10.45 WIB. Kegiatan pendampingan Pembelajaran bahasa Inggris di hari pertama yang dilaksanakan pada tanggal 6 Oktober jam 09.30-10.45 WIB, dimulai dengan berdoa, selanjutnya modul pembelajaran bahasa Inggris diberikan kepada para peserta. Sebelum mengerjakan soal-soal yang terdapat dalam modul pengayaan bahasa Inggris, kami menanyakan sampai sejauh mana pembelajaran bahasa Inggris yang mereka pelajari selama ini terutama sebelum dan selama pandemi Covid 19. Berdasarkan jawaban yang didapatkan dari para peserta, kami memulai dengan penjelasan mengenai apa yang akan dipelajari dan memotivasi para peserta sebelum pelaksanaan pembelajaran Bahasa Inggris. Berikut ini adalah gambar pelaksanaan pertama dan memberikan motivasi kepada para peserta pendampingan pembelajaran Bahasa Inggris.

Setelah dimulai dengan doa dan memotivasi para peserta yang tergabung dalam program pemberdayaan masyarakat berupa pendampingan, kami beserta anggota tim mulai membagi tugas antara lain dengan 
menerangkan apa saja yang dilakukan oleh para peserta pembelajaran bahasa Inggris bagi anak kelas V SD. Pertama yang kami terangkan adalah what time it is. Bagian ini adalah mengajarkan anak-anak mengenal waktu dalam bahasa Inggris. Dalam pembelajaran ini ada beberapa hal yang harus dikerjakan yaitu bagian pertama adalah sub bagian II. Study these sentences, sub bab III study these dialogue. Kemudian dilanjutkan dengan mengerjakan latihan individual work. Berikut ini adalah gambar dari bagian modul pembelajaran bahasa Inggris.

Sedangkan bagi kelas IV SD mempelajari modul pengayaan dengan materi I want to introduce Myself dengan beberapa sub bagian yaitu sub bagian II study dialogue, group work berupa dialogue dan diakhiri dengan Competency test. Untuk kelas I SD penggunaan Modul pengayaan dimulai dengan greeting dan mengenali bagaimana penggunaan greeting. Untuk satu orang anak siswa kelas VII MTs pertama diberikan pengenalan mengenai struktur kalimat Bahasa Inggris, kemudian mengenali jenis dan fungsi kata Bahasa Inggris dalam menyusun kalimat, dilanjutkan dengan pengenalan tenses yaitu simple present tense, kemudian diajarkan rumus kalimat positif, negatif dan interogatif.

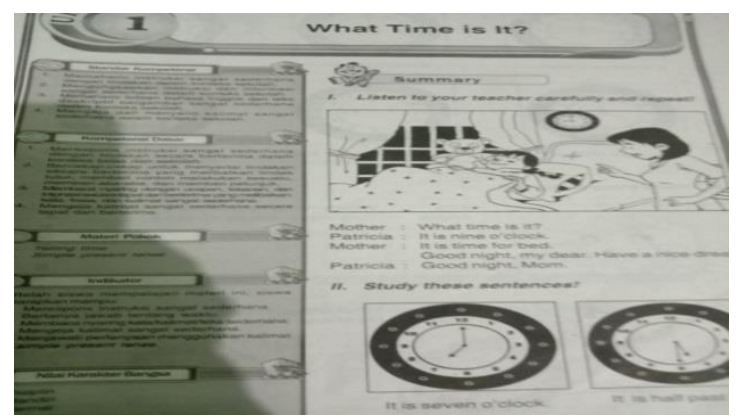

Gambar 2. Modul pengayaan bahasa Inggris kelas 4

Pelaksanaan pertemuan-pertemuan selanjutanya dilaksanakan pada minggu pertama bulan Oktober yaitu tanggal 8, 9, 10, minggu kedua yaitu pada tanggal 13, 15, dan 17. Minggu ketiga dilaksanakan pada tanggal 20, 22 dan 24. Minggu keempat 27,
29, dan yang terakhir tanggal 31 Oktober. Beberapa materi yang diajarkan untuk 3 orang anak siswa kelas I adalah Unit 1. Good afternoon Lisa, kemudian unit 2. Hello Doni. Selanjutnya Unit 3 Spell your name dan saat ini sampai unit 4 there are five mangoes. Untuk dua orang anak siswa kelas IV pendampingan pembelajaran bahasa Inggris, unit 1. I want to introduce myself, kemudian Unit 2. Good morning, Mom, lalu dilanjutkan Unit 3. She has six dolls. Terakhir di minggu keempat adalah unit 4. Si-Ei-Ti, Cat. Sedangkan untuk dua orang anak siswa kelas $\mathrm{V}$ yang dipelajari selama 4 minggu pendampingan pembelajaran adalah unit 1. What time is it? Kemudian Unit 2. Today is Sunday, lalu dilanjutkan ke unit 3. What date is tomorrow? Kemudian di minggu ke empat unit 4. He studies at $7 \mathrm{pm}$.

Di Bulan Oktober tanggal 8, 9, 10, minggu kedua yaitu pada tanggal 13,15 , dan 17. Minggu ketiga dilaksanakan pada tanggal 20, 22 dan 24. Minggu keempat 27, 29, dan yang terakhir tanggal 31 Oktober. Beberapa materi yang diajarkan untuk 3 orang anak siswa kelas I adalah Unit 1. Good afternoon Lisa, kemudian unit 2. Hello Doni, selanjutnya Unit 3 Spell your name dan saat ini sampai unit 4 there are five mangoes. Untuk dua orang anak siswa kelas IV pendampingan pembelajaran Bahasa Inggris, unit 1. I want to introduce myself, kemudian Unit 2. Good morning, Mom, lalu dilanjutkan Unit 3. She has six dolls. Terakhir di minggu keempat adalah unit 4. Si-Ei-Ti, Cat. Sedangkan untuk dua orang anak siswa kelas $\mathrm{V}$ yang dipelajari selama 4 minggu pendampingan pembelajaran adalah unit 1 . What time is it? Kemudian Unit 2. Today is Sunday, lalu dilanjutkan ke unit 3. What date is tomorrow? Lalu di minggu ke empat unit 4. He studies at $7 \mathrm{pm}$.

Bagi satu orang anak kelas VII MTs pada minggu pertama fokus pada belajar bagaimana membuat kalimat yang benar dengan mempelajari struktur kalimat Bahasa Inggris dan mengenali jenis dan fungsi kata Bahasa Inggris dalam menyusun 
sebuah kalimat bahasa Inggris yang berkaitan dengan kebiasaan yang dilakukan sehari-hari. Kemudian minggu kedua dilanjutkan dengan memuat kalimat-kalimat yang berkaitan dengan anggota keluarga. Pada minggu ketiga materi pembelajaran mengenai simple past tense, rumus kalimat positif, negatif dan interogatif, yang kemudian dilanjutkan dengan menulis pengalaman sebelum masa pandemic Covid 19. Materi terakhir adalah future tense, dilanjutkan dengan rumus kalimat positif, negatif, dan interogatif. Kemudian membuat kalimat rencana di masa yang akan datang.

\section{HASIL DAN LUARAN}

Pada pertemuan pertama terlihat beberapa peserta kesulitan dalam memperkenalkan diri dalam Bahasa Inggris. Hal tersebut dapat dimaklumi karena semua peserta yang mengikuti pendampingan ini sudah tidak mengikuti pertemuan tatap muka selama kurang lebih 6 bulan. Bahkan bagi peserta kelas 1 mereka sama sekali belum pernah masuk mengikuti pelajaran tersebut. Oleh karena itu dibutuhkan kesabaran dan pengulangan beberapa kali untuk memperbaiki pelafalan dan kelancaran dalam berbahasa Inggris. Sedangkan bagi kelas 4 terdapat satu siswa yang kesulitan dalam mengerjakan tugas yang ada dan harus terus diberikan bimbingan oleh tim dalam mengisi jawaban dan mengulang kalimat-kalimat yang terdapat dalam modul yang dibagikan.

Sedangkan bagi peserta kelas 5 dan kelas 7 SMP tidak terdapat kesulitan yang berarti. Dua peserta dari kelas 5 mampu mengerjakan soal-soal yang terdapat dalam modul yang diberikan setelah diberikan penjelasan dan latihan yang terdapat dalam modul. Sedangkan bagi 1 peserta kelas 7 SMP, terlihat sangat antusias dengan pendampingan tersebut. Hal ini bisa dilihat dari hasil pengerjaan pelatihan yang terdapat dalam modul yang hampir semuanya benar. Peserta tersebut juga bisa mengerjakan PR yang diberikan oleh gurunya.
Pada pertemuan minggu kedua dan ketiga mulai terlihat kemampuan Bahasa Inggris para peserta meningkat dengan baik.

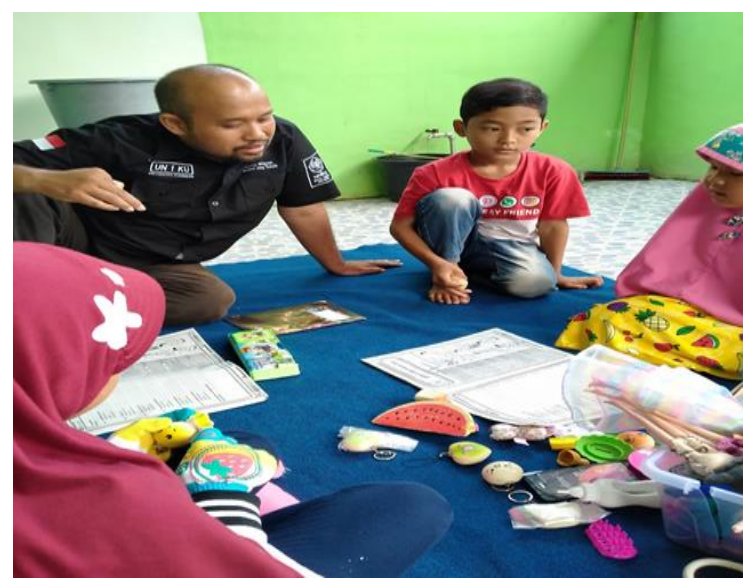

Gambar 3. Pertemuan minggu pertama

Hal tersebut dapat dilihat dari hasil tugas yang diberikan oleh tim pengabdian melalui modul yang diberikan oleh tim sebelumnya. Pada peserta kelas 1 sudah mampu mengerjakan tugas-tugas yang terdapat dalam modul pembelajaran, dan ketika diminta untuk membaca dengan keras para peserta tersebut dengan percaya diri membacanya, hanya sedikit membuat kesalahan dalam pengucapannya. Hal yang sama juga dapat dilihat dari para peserta kelas 4, 5, dan 7, mereka tidak menemukan kesulitan yang berarti dalam mengerjakan tugas-tugas yang diberikan oleh tim setelah pendampingan pembelajaran dilaksanakan.

Setelah pelaksanaan pendampingan pembelajaran Bahasa Inggris bagi siswa SD dan SMP selama beberapa minggu, tim melaksanakan evaluasi pada pelaksanaan program ini dengan menguji kemampuan para peserta yang telah mengikuti pendampingan dengan tes-tes yang terdapat pada modul ulangan yang disusun berdasarkan tingkat atau kelas dari peserta pendampingan. Hasil dari evaluasi baik dari kemampuan membaca Bahasa Inggris dengan menjawab essay, memilih jawaban dari pilihan ganda melampaui nilai minimum ketuntasan dari kompetensi tersebut. Selain itu para peserta juga mampu menghapalkan dan melafalkan kata-kata Bahasa Inggris dengan baik dan benar. 
Berdasarkan interview yang dilaksanakan oleh tim, para peserta pendampingan merasa lebih percaya diri dalam mengerjakan tugas sekolah maupun ujian harian pelajaran Bahasa Inggris yang diberikan oleh guruguru mereka.

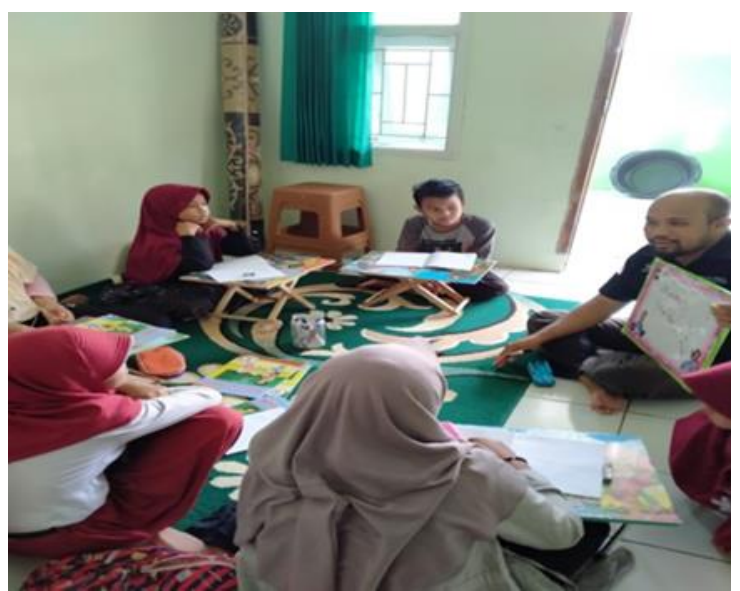

Gambar 4. Pertemuan ketiga

Refleksi kegiatan pendampingan pembelajaran Bahasa Inggris bagi anak SD dan SMP di Perumahan Griya Nuansa Lestari ini dilakukan di akhir minggu keempat mengenai hasil dan luaran pelaksanaan program pendampingan pembelajaran Bahasa Inggris yang dilaksanakan bersama para peserta pendampingan pembelajaran dengan didampingi para pengurus Rumah Belajar GNL. Berdasarkan diskusi bersama anggota tim serta pengurus Rumah belajar GNL peserta pendampingan belajar dan hasil feedback dari para orang tua siswa dapat diambil kesimpulan bahwa para peserta pendampingan dan para orang tua merasa sangat terbantu dengan program ini. Hal tersebut dapat dilihat dari tingkat kehadiran dalam setiap pelaksanaan kegiatan yang mendekati 100 persen, serta perkembangan kemampuan anak-anak yang tergabung dalam kegiatan ini yang cukup signifikan. Hal ini dapat dilihat dari hasil pekerjaan rumah dan ulangan-ulangan harian mereka. Luaran lainnya adalah dukungan datang dari para orang tua yang berusaha mendorong anaknya untuk datang ke tempat pelaksanaan kegiatan pendampingan ini bahkan para peserta datang tanpa diantar oleh orang tuanya.

\section{KESIMPULAN DAN SARAN}

Kesimpulan

Berdasarkan hasil refleksi dari kegiatan pengabdian masyarakat berupa pendampingan pembelajaran Bahasa Inggris yang telah dilakukan selama satu bulan mulai awal bulan yaitu pada tanggal 5 Oktober sampai dengan tanggal 31 Oktober dianggap sukses. Hal tersebut dapat dilihat dari tingkat kehadiran dalam setiap pelaksanaan kegiatan yang mendekati 100 persen. Dukungan lainnya datang dari para orang tua yang berusaha mendorong anaknya untuk datang ke tempat pelaksanaan kegiatan bahkan para peserta datang tanpa diantar orang tuanya.

Saran

Berdasarkan masukan dari para pengurus Rumah Belajar GNL serta orang tua siswa diharapkan program pengabdian masyarakat yaitu program pendampingan pembelajaran tidak selesai hanya pada saat program hibah pengabdian masyarakat internal Universitas Kuningan berlangsung, tetapi tetap dilanjutkan di masa yang akan datang terutama selama masa pembelajaran di rumah yang diakibatkan lock down yang telah dilakukan beberapa kali. Selain itu para pengurus Rumah Belajar GNL dan para orang tua berharap pendampingan pembelajaran tidak hanya untuk pembelajaran Bahasa Inggris tapi juga untuk mata pelajaran yang lain seperti mata pelajaran matematika dan lain-lain. Selain itu mereka meminta jumlah peserta ditambah karena masih ada yang tidak bisa mengikuti program ini karena protocol Covid 19 dan keterbatasan ruang.

\section{UCAPAN TERIMA KASIH}

Tim pengabdia masyarakat mengucapkan terima kasih kepada Universitas Kuningan yang telah membiayai program pengabdian masyarakat, yaitu berupa program pendampingan pembelajaran Bahasa Inggris bagi anak- 
anak di Rumah Belajar GNL melalui program Hibah Internal Pengabdian Masyarakat Universitas Kuningan. Selanjutnya tim pengabdi juga mengucapkan terima kasih kepada para pengurus Rumah Belajar GNL yang diinisiasi oleh para ibu rumah tangga yang diketuai oleh Ibu Dewi Puspasari dan para pengurus lainnya. Tidak lupa kepada para peserta pendampingan pembelajaran serta dukungan penuh para orang tua selama program pengabdian masyarakat dilaksanakan.

\section{DAFTAR PUSTAKA}

Apriliana, N. (2018). The Implementation of Teaching English to Young Learners in Public Primary Schools in Pringsewu, Lampung Province, Indonesia. Kajian Linguistik dan Sastra. 3 (1).

Baihaqi, Y. (2016). The Eeffectiveness of Using Task Based Language Teaching (TBLT) In Teaching The Students' English Speaking Ability at The Eleventh Grade of SMK Penerbangan AAG Adisustjipto Yogyakarta. Premise Journal. 5 (1).

Brow, H. D. (2001). Teaching by Principles. New York: Longman Inc

Ellis, R. (2003). Task-Based Language Learning and Teaching. New York: Oxford Uni- versity Press.

Fahaturnnisa, A. (2019). The Implentation of Task-Based Language Teaching in Teaching Writing. The lst Bogor English Student and Teacher (BEST) Conference 2019. 1, 30-34.

Nurbani (2017). Teaching English for EFL Young Learners Using Task Based Langauge Teaching. 1 st International Conference on Teaching and Education. Volume 1, page 176-180. Sinatra, A. F. (2009). Optimizing TaskBased Activity to Improve Students' Speaking Ability. Tesis tidak dipublikasikan. Solo: Universitas Sebelas Maret.
Skehan, P. (1998). A Cognitive Approach to Language Learning. New York: Oxford University Press.

\section{Peraturan Perundang-Undangan}

Undang-Undang Nomor 12 tahun 2012 tentang Pendidikan Tinggi.

Surat Edaran Nomor 15 Tahun 2020 tentang Pedoman Penyelenggaraan Belajar Dari Rumah Dalam Masa Darurat Penyebaran Corona Virus Disease (Covid 19) 